\title{
LICHEN COMMUNITY RESPONSE TO PRESCRIBED BURNING AND THINNING IN SOUTHERN PINE FORESTS OF THE MID-ATLANTIC COASTAL PLAIN, USA
}

\author{
David G. Ray ${ }^{*}$, Jason W. Barton ${ }^{2}$, and James C. Lendemer ${ }^{2}$ \\ ${ }^{1}$ The Nature Conservancy, Maryland-District of Columbia Chapter \\ 116 South Saratoga Street, Salisbury, Maryland 21804, USA \\ ${ }^{2}$ Institute of Systematic Botany, New York Botanical Garden, \\ 2900 Southern Boulevard, Bronx, New York 10458, USA \\ *Corresponding author: Tel.: 1+850-241-6837; e-mail: d_ray@tnc.org \\ ABSTRACT

\section{RESUMEN}

The effects of prescribed burning and thinning on lichen communities is a poorly understood aspect of biodiversity conservation, despite the widespread use of these practices to achieve conservation-oriented land management goals. To address this knowledge gap we documented apparent changes in the diversity and abundance of lichens following 0 to 2 growing-season burns preceded by 0 to 1 commercial thinnings within nine southern pine dominated stands on the Delmarva Peninsula of Maryland, USA. Corticolous lichens growing on the stems and within the canopies of pines and co-occurring hardwoods were identified to species and fractional coverage was estimated; growth forms and reproductive modes were also determined. A total of 93 lichen taxa were recorded on the 19 tree species (4 pines, 15 hardwoods) represented in this study. Burning emerged as a strong driver of reductions in lichen diversity $(P=0.002)$, whereas thinning in the absence of burning did not $(P=0.279)$. In general, we found that lichens growing on tree bases and lower bole sections were more strongly impacted by burning, both in terms of
Los efectos de quemas prescriptas y raleos sobre comunidades de líquenes es un aspecto poco comprendido de la conservación de la biodiversidad, a pesar del extenso uso de esas prácticas para lograr metas de manejo orientadas a la conservación. Para llenar este vacío en el conocimiento, documentamos los cambios aparentes en la diversidad y abundancia de líquenes de 0 a 2 temporadas de crecimiento después de las quemas y precedidas de 0 a 1 raleo comercial, dentro de nueve rodales dominados por pinos del sur en la península de Delmarva en Maryland, EEUU. Los líquenes cortícolas creciendo en tallos y dentro del dosel arbóreo de pinos y latifoliadas circundantes, fueron identificados a nivel de especie y se estimó la fracción de su cobertura; las formas de crecimiento y modos reproductivos fueron también determinados. Un total de 93 taxones de líquenes sobre 19 especies de árboles (4 pinos y 15 latifoliadas) fueron registrados en este estudio. Las quemas emergieron como fuertes conductoras en la reducción de la diversidad de líquenes $(P=0.002)$, mientras que los raleos en ausencia de quemas no tuvieron ningún efecto $(P=0.279)$. En general, encontramos que los líquenes que crecen en la base de los árboles y en las porciones bajas del tronco fueron más impactados por las quemas, tanto en diversidad como en cobertu- 
diversity and cover, than those residing in the canopy. The apparent refugia represented by the canopy was qualified by the limited overlap in lichen species composition observed among the various sampling heights. This work calls attention to an understudied component of biodiversity that appears to be sensitive to fire management; however, we suggest that these results need to be interpreted in the context of altered disturbance regimes and the trajectory of community assembly resulting from long-term fire exclusion. ra, que aquellos ubicados en el dosel. El aparente refugio representado por el dosel fue estimado por la limitada superposición en la composición de especies de líquenes observados entre las distintas alturas de muestreo. Este estudio llama la atención sobre un aspecto poco estudiado de la biodiversidad que aparenta ser sensible al manejo del fuego; desde luego, sugerimos que estos resultados deben interpretarse en el contexto de regímenes de disturbios alterados y la trayectoria del ensamble de la comunidad resultante de la exclusión del fuego por largos períodos de tiempo.

Keywords: biodiversity, disturbance regime, lichens, prescribed burning, restoration, southern pines, thinning, woodlands

Citation: Ray, D.G., J.W. Barton, and J.C. Lendemer. 2015. Lichen community response to prescribed burning and thinning in southern pine dominated woodlands of the Mid-Atlantic Coastal Plain, USA. Fire Ecology 11(3): 14-33. doi: 10.4996/fireecology.1103014

\section{INTRODUCTION}

Terrestrial biodiversity has been substantially diminished by anthropogenic factors including land-use change, altered disturbance regimes, and, increasingly, as a result of global climate change (IPCC 2013). Contributing to these trends, substantial areas of mixed-species upland forest in the Mid-Atlantic Coastal Plain region of the US have been displaced by agriculture and development or converted to intensively managed pine plantations (Auch 2000). Contemporary approaches to land management that seek to re-establish missing elements of ecosystem composition, structure, and function in order to enhance biodiversity and resilience typically embrace approaches grounded on historic disturbance regimes (Kohm and Franklin 1997, Seymour et al. 2002, Egan 2005, Mitchell et al. 2006, Wiens et al. 2012).

Wildland fires, both natural and human caused, have shaped forest communities and influenced plant specialization for millennia in eastern North America (Whitney 1994, Delcourt and Delcourt 1997, Frost 1998, Platt 1999, Ryan et al. 2013). However, European settlement altered extant fire regimes, culminating in government agency policies that greatly reduced the number and area of wildland fires throughout the twentieth century (Pyne 1982, 2010). As a result, historic woodland and savanna systems in eastern North America have largely been transformed into closed-canopy forests through the recruitment of shade-tolerant, fire-sensitive vegetation (Anderson 1991, Wolf 2004, Bond et al. 2005, Nowacki and Abrams 2008). It is now widely accepted that many ecosystems in eastern North America depend on periodic burning to maintain plant communities and associated habitats for native wildlife. Prescribed burns are increasingly used in an effort to reverse the detrimental impacts that fire exclusion has had on these fire-adapted ecosystems (Platt 1999, Brooks et al. 2004, Agee and Skinner 2005, Ryan et al. 2013). 
Similar to fire exclusion, forest management and, more specifically, practices commonly associated with intensive southern pine silviculture (e.g., site preparation, herbicide release, fertilization, and maintenance of high stocking) are also widely considered to have negative impacts on biodiversity. While not without merit, this view can be overly simplistic, and approaches have been suggested to mitigate some of the negative impacts of these practices (Andreu et al. 2008, Hartmann et al. 2010). Coxson and Stevenson (2005) reported on the short-term impacts of partial harvesting practices on canopy lichens in mixed conifer forests of British Columbia, Canada, concluding that, while species exhibiting pendulous growth forms were susceptible to wind damage, the other groups that they studied appeared relatively unaltered by the treatments.

In contrast to the extensive body of literature describing the response of vascular plants to prescribed burning, similar resources are not currently available for lichens (see FEIS 2015). Lichens are symbiotic organisms comprised primarily of a fungus and an alga that form a single unit in which the fungus tends to dominate (Brodo et al. 2001). They are recognized as keystone members of terrestrial ecosystems, performing diverse services contributing to nitrogen fixation, animal forage, soil stabilization, and moisture retention, and hosting diverse and unique communities of bacteria, fungi, and other microorganisms (Brodo et al. 2001, Arnold et al. 2009, Hodkinson and Lutzoni 2009, Gauslaa 2014). Despite their importance, many aspects of lichens, from taxonomy to basic biology, remain understudied (Brodo et al. 2001, Lendemer and Allen 2014). Similarly, lichens have demonstrated utility as indicator species for environmental pollution and degradation (Nash 1975, Showman 1981, Muir and McCune 1988, Wolseley 1995, McCune et al. 1997), yet their responses to disturbances and how disturbance regimes shape the composition and structure of lichen communities has yet to be studied in many ecosystems.
The majority of studies documenting the relationship between lichens and disturbance regimes suggest that lichens are highly impacted by burning, both in terms of diversity and abundance, across a range of habitats (Klein 1982, Antos et al. 1983, Mistry 1998, Reinhart and Menges 2004, Johansson and Reich 2005). Reduced lichen cover may persist in burned areas due to slow growth and colonization rates, and as the result of unprotected organelles in ground-layer lichens (Antos et al. 1983, Holt and Severns 2005). Nonetheless, a study of reindeer lichens (Cladonia spp. P. Browne) in grasslands of Minnesota, USA, suggests that recovery is largely a factor of fire intensity and frequency, whereby lichens subjected to low intensity fires are quicker to recover compared to those exposed to higher intensity burns (Johansson and Reich 2005). Many of the studies detailing lichen community response to fire in North America have focused on soil lichens within grassland habitats of the West (Bowker et al. 2004, Holt and Severns 2005, Johansson and Reich 2005), and therefore provide limited insight to the response of corticolous lichen communities in forest and woodland settings.

Because prescribed burning and tree density reduction (i.e., thinning) represent the most widely used management techniques being employed to restore and promote resiliency within overly dense, fire-excluded forests, we sought to better understand the impacts of these practices on affiliated lichen communities. Here we present the results of an observational study describing the short-term effects of these treatments on corticolous lichens within southern pine forests of the Mid-Atlantic Coastal Plain. The study was undertaken in the broader context of a large-scale inventory of lichens on protected lands throughout the region, which revealed unexpectedly high levels of diversity, including on the Delmarva Peninsula (Lendemer and Allen 2014). Discussions undertaken with land managers and agency officials during the larger project re- 
vealed that, although these practices were being used to achieve conservation benefits in this region, the possible impacts of these management actions on lichen communities were not being considered and were largely unknown.

\section{METHODS}

\section{Study Area}

This study took place on Nassawango Creek Preserve located in Wicomico and Worcester counties, on the Eastern Shore of Maryland, USA ( $38^{\circ} 16^{\prime} 09.5^{\prime \prime} \mathrm{N} 75^{\circ} 28^{\prime} 15.2^{\prime \prime}$ $\mathrm{W}$; Figure 1). The $\sim 4050$ ha property is owned and managed by The Nature Conservancy and was acquired for the purpose of biodiversity and watershed protection beginning in the late

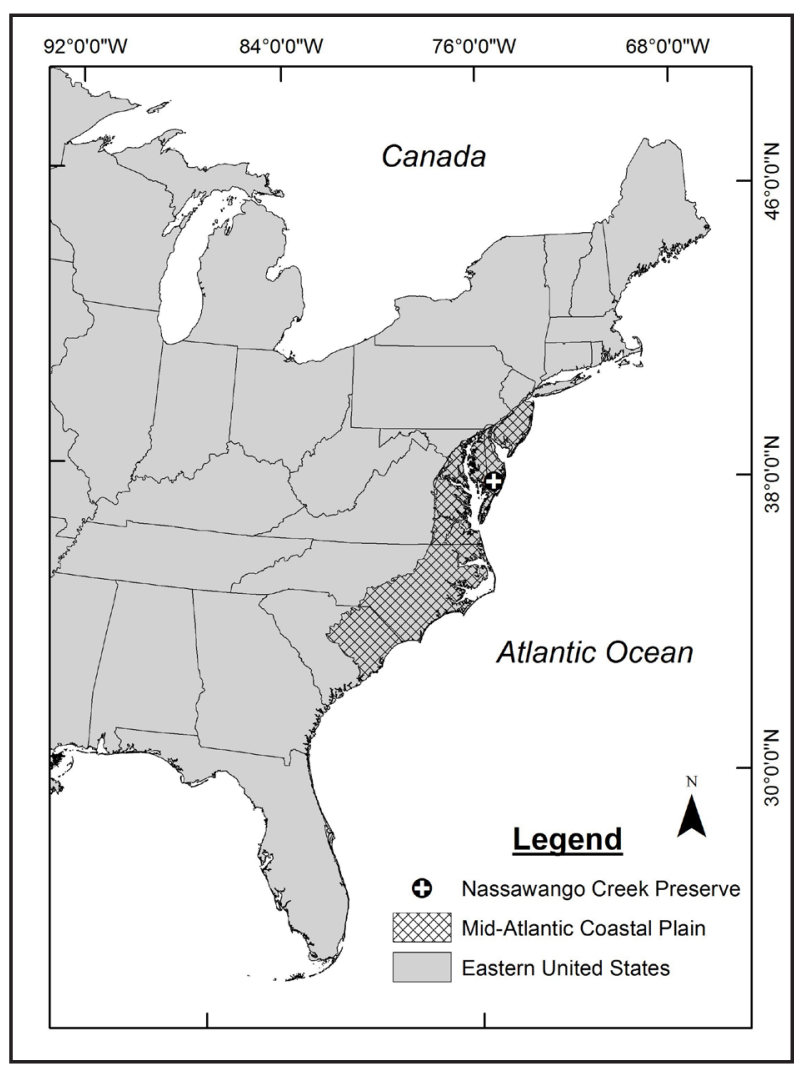

Figure 1. Map of the Mid-Atlantic Coastal Plain showing the location of the study area on the lower Eastern Shore of the Delmarva Peninsula, Maryland, USA 1970s. Floodplain forests dominated by bald cypress (Taxodium distichum [L.] Rich.), black gum (Nyssa sylvatica Marshall), and red maple (Acer rubrum L.) predominate across much of the Preserve. Excessively drained and nutrient-poor upland sites known as inland dunes (Denny and Owens 1979) account for roughly $10 \%$ of the land base and, by contrast, host a variety of fire-adapted woodland species. Under historic or pre-European settlement conditions, the inland dunes are thought to have been vegetated by drought-tolerant tree species including oaks (white oak [Quercus alba L.], black oak [Q. velutina L.], blackjack oak [Q. marilandica Münchh.], post oak [Q. stellata Wangenh.]), sand hickory (Carya pallida [Ashe] Engl. \& Graebn.), and southern pines (loblolly pine [Pinus taeda L.], shortleaf pine [P. echinata Mill.], Virginia pine [P. virginiana Mill.]). Understory vegetation on the dunes is typically characterized by a diversity of pyrogenic herbaceous, grass, and shrub species, at least when a sufficient canopy openness is maintained (Harrison 2011, NatureServe 2011).

The region has a complex and lengthy land-use history, wherein extensive areas of wetland forests were drained and converted to productive agriculture and plantation forestry. Despite the lower productivity of plantations grown on the inland dunes, the fact that this ground remains operable by heavy equipment throughout the year makes it a valuable asset to the forest industry during periods of wet weather. As a result, loblolly pine is often the dominant tree species encountered on these sites and within adjacent upland ecotones, where this study took place. Restoration practices, including the re-introduction of fire, reduction of tree stem density, and enrichment planting with site-adapted species, are being implemented to enhance the biodiversity and habitat values of degraded inland dunes and affiliated uplands across the property.

An observational study design was used to characterize differences in lichen community 
response to restoration management practices while controlling, to the extent possible, for edaphic setting, stage of stand development, and tree composition. Study plots were established in middle-aged (20 yr to $40 \mathrm{yr}$ ) pine stands that were previously (1) thinned but not burned ( $n=3$ stands; code $=10)$, (2) thinned once and burned once $(n=2$ stands; code $=$ $11),(3)$ thinned once and burned twice $(n=2$ stands; code $=12$ ), or (4) an unaltered reference $(n=2$ stands; code $=00)$. Thinning to reduce canopy density was accomplished with conventional logging equipment and always occurred at least one year prior to burning. Pine tree basal areas on the thinned plots were reduced to between $16.1 \mathrm{~m}^{2} \mathrm{ha}^{-1}$ and $18.4 \mathrm{~m}^{2}$ $\mathrm{ha}^{-1}$ by commercial thinning treatments carried out between 2007 and 2012. Prescribed burns were conducted during the early growing season (March through May). Descriptions of the treatments are presented in Table 1.

\section{Sample Selection}

Corticolous lichens were sampled from trees growing on plots drawn from a nominal 2 ha systematic grid used for forest inventory on the property. The sample trees were selected as follows: within a search radius of $15.2 \mathrm{~m}$ from the plot center and in a randomly selected quadrat (i.e., NE, SE, SW, NW), we chose the closest tree of each species within two diameter-based size classes $(2.54 \mathrm{~cm}$ dbh to 11.2 $\mathrm{cm} \mathrm{dbh}$, and $>11.2 \mathrm{~cm} \mathrm{dbh).} \mathrm{One} \mathrm{representa-}$ tive of each tree species was sought within each size class on each plot. Species present at lower densities were searched for within the remaining quadrats until the entire plot area was used $\left(730 \mathrm{~m}^{2}\right)$.

Lichens were inventoried on each of the selected trees within established sampling heights based on three height categories: (1) base (forest floor to $0.3 \mathrm{~m}$ up the stem), (2) bole $(0.3 \mathrm{~m}$ to $2.4 \mathrm{~m}$, or up to the lowest live branch within the tree canopy), and (3) canopy (defined as the lowest live branch, excluding epicormic sprouts). Measurement of lichens on the base and bole sections of the stem were accomplished from the ground, whereas canopy samples were either collected from the ground with a pole saw or required climbing equipment to excise the selected branch. Lichen thalli were identified and recorded in the field within each sampling interval. Voucher specimens for each species identified on a plot were collected. Vouchers were later examined

Table 1. Selected attributes of the study plots including the timing of commercial thinning and prescribed burns (Treatment: $00=$ control; $10=$ thinned, not burned; $11=$ thinned, burned once; $12=$ thinned, burned twice). Means and standard deviations for basal area (BA) and average stand diameter (Dq), and the relative abundance of pines to hardwoods (Pine BA, \%). na = not applicable.

\begin{tabular}{cccccccc}
\hline Treatment & $\begin{array}{c}\text { Stand } \\
\text { name }\end{array}$ & $\begin{array}{c}\text { Plot } \\
(\boldsymbol{n})\end{array}$ & Thinning & Prescribed burn & $\begin{array}{c}\text { BA } \\
\left.\mathbf{( m}^{\mathbf{2}} \mathbf{h a}^{-1}\right)\end{array}$ & $\begin{array}{c}\text { Pine BA } \\
\mathbf{( \% )}\end{array}$ & $\begin{array}{c}\text { Dq } \\
(\mathbf{c m})\end{array}$ \\
\hline 00 & Ace & 2 & na & na & $26.5 \pm 11.4$ & 55 & $21.7 \pm 1.3$ \\
00 & Laws & 4 & na & na & $39.7 \pm 8.3$ & 81 & $22.8 \pm 3.2$ \\
10 & Ches/Som & 2 & 2011 & na & $16.1 \pm 13.0$ & 72 & $23.5 \pm 1.6$ \\
10 & SCI-P2 & 3 & 2005 & na & $23.0 \pm 4.0$ & 87 & $21.7 \pm 1.5$ \\
10 & WIC-5 & 4 & 2013 & na & $16.7 \pm 8.3$ & 95 & $28.5 \pm 5.3$ \\
11 & WIC-2 & 4 & 2007 & May 2011 & $27.6 \pm 13.9$ & 96 & $26.6 \pm 4.5$ \\
11 & WOR-1 & 2 & 2006 & April 2011 & $16.1 \pm 6.5$ & $\sim 100$ & $26.9 \pm 3.6$ \\
12 & WOR-4 & 4 & 2005 & April 2009, April 2013 & $19.0 \pm 8.3$ & $\sim 100$ & $27.9 \pm 2.3$ \\
12 & WOR-7 & 2 & 2007 & April 2011, May 2013 & $13.8 \pm 6.5$ & $\sim 100$ & $22.5 \pm 0.5$ \\
\hline
\end{tabular}


in the lab using compound and dissecting microscopes, chemical spot test, and thin layer chromatography when appropriate. All vouchers were deposited in the New York Botanical Garden, Bronx, New York, USA. In addition to abundance (counts for a given species within a sampling height), cover was also visually estimated in the field for each lichen taxon recorded. Cover was placed into five groups as follows: 1 ( $1 \%$ to $5 \%), 2$ (6\% to $25 \%), 3$ (26\% to $50 \%), 4(51 \%$ to $75 \%)$, and $5(76 \%$ to $100 \%)$. An estimate of total lichen cover for each sampling interval was also made independent of those for the individual taxa. For the purposes of assessing growth form and reproductive mode, a table of all species found during the study was produced and these characters were scored for all taxa using existing references and standard literature. This resulted in the assignment of a growth form (i.e., crustose, foliose, fruticose) and reproductive mode (asexual vs. sexual) to each taxon.

\section{Statistical Analyses}

Estimates of lichen diversity and cover obtained from the individual trees $(n=177)$ were treated as sub-samples, and values for the experimental unit, represented by plots $(n=27)$ for correlation and stands $(n=9)$ for Anova, were arrived at by either summing (for diversity measures) or averaging (for cover) over the sub-samples. Dependent variables were calculated for each plot or stand and sampling height $($ Base $=$ BAS, Bole $=$ BOL, Canopy $=$ CAN) as follows: (1) lichen diversity (taxa) was determined as the number of unique taxa observed across all trees, (2) lichen cover (cover) as the average of the fractional cover estimate for each sampling height, (3) lichen morphology (growth form) as the proportion of lichens within three categories (crustose, foliose, and foliose) across treatments, and (4) lichen reproductive strategy (reproductive mode) as the proportion of lichens exhibiting either sexual or asexual reproductive struc- tures (indeterminate samples were discarded from the analysis) across treatments.

Sørensen similarity values (Sørensen 1948) were used to compare lichen taxa among sampling heights, (i.e., BAS and BOL, BOL and $\mathrm{CAN}$, and BAS and CAN). Values were calculated using EstimateS for Windows v9.10 (Colwell 2013) by tree species group (hardwoods $=\mathrm{HW}$, pines $=\mathrm{PI}$ ) for each treatment category. More formal analysis was not possible with this dataset due to a preponderance of missing values on the burned plots, which resulted in a highly unbalanced dataset. A combination of factors contributed to this occurrence, but it was largely attributable to lichens having been eliminated from the BAS sampling height of trees in the burn treatments. The zero values in this analysis correspond to situations in which lichens were present within both heights that were being compared, but no taxa were common to both.

We took an analysis of variance approach to assessing how lichen communities were impacted by the treatments. Models of the following general form were used to evaluate the contribution of independent variables:

$$
\begin{aligned}
& \text { taxa or cover or growth form or } \\
& \text { reproductive mode }=\text { treat }+ \text { cov, }
\end{aligned}
$$

where the lichen variables were determined in total or at the different sampling heights, treat is a class variable describing the combination of fire and thinning treatments $(n=4$, coded $00,10,11,12)$, and cov is a quantitative covariate representing the number of hardwood species sampled in each stand. This variable was included in an attempt to account for known differences in the morphology and chemistry of tree bark between pines and hardwoods as they relate to lichen occupancy (Culberson 1955, Schmitt and Slack 1990). Owing to the small sample size available for this analysis, a limited number of contrasts were chosen a priori for evaluation with post hoc significance tests. Specifically, we compared the 
burned and unburned $(00+10=11+12)$, and the thinned and unthinned $(00=10)$ treatments. The GLM procedure in SYSTAT 12 (SYSTAT Software, San Jose, California, USA) was used to carry out all statistical tests.

\section{Quantification of Fire Severity}

Methods developed by the Monitoring Trends in Burn Severity program (MTBS; http://www.mtbs.gov/index.html) were used to obtain plot-level estimates of fire impacts on the vegetation (e.g., Picotte and Robertson 2011). Paired Landsat scenes collected approximately one year before and as soon as possible following the prescribed burns provided the basis for this assessment. The value of the fire severity variable (differenced normalized burn ratio, dNBR) determined at each plot location was paired with lichen taxa and cover variables. For this analysis, the lichen taxa variable was given by the cumulative number of lichen species recorded on each plot by tree species group (PI and HW), and lichen cover as the average of the base, bole, and canopy sampling heights. The highest value of the dNBR variable recorded for each plot was used to describe fire severity on the twice-burned plots $\left(\mathrm{dNBR}_{\mathrm{MAX}}\right)$. Simple correlation analysis was used to assess the strength of the relationship between fire severity and the lichen variables.

\section{RESULTS}

Considering the availability of different substrates for corticolous lichens, hardwood tree species were notably more common on the unburned than burned plots (Table 2), and large-sized hardwoods were limited to the reference plots. Of the common hardwood species, only sweetgum (Liquidambar styraciflua L.), southern red oak (Quercus falcata Michx.), and sassafras (Sassafras albidum [Nutt.] Nees) were substantially represented on both the burned and unburned plots. Fur- thermore, the hardwood species on the burned plots were typically found in subordinate crown positions to the pines, within the midstory layer, presumably as a result of past cultural treatments (i.e., broadcast herbicide release to favor the pines). A number of more mesic and generalist species, including red maple, American holly (Ilex opaca Aiton), and water oak (Q. nigra L.), were also well represented on the unburned plots. Pines, and most notably loblolly pine, were a dominant feature across all the study plots (Table 2). On average, tree basal areas (BA, $\left.\mathrm{m}^{2} \mathrm{ha}^{-1}\right)$ were highest in the reference areas and lowest in stands that had been thinned and burned twice, although these values varied considerably among plots within a treatment (Table 1).

A grand total of 93 lichen species were found growing on trees sampled in this study. Among these, 76 were found on trees in the reference areas $(\mathrm{T}=00), 83$ in the thinned and unburned plots $(\mathrm{T}=10), 35$ in the thinned and once-burned plots $(\mathrm{T}=11)$, and 8 in the thinned and twice-burned plots $(\mathrm{T}=12)$. Trends in tree species diversity paralleled those for the lichens, with 16 tree species represented in the reference, 13 in the thinned, 5 in the thinned and burned, and 3 in the thinned and twice-burned stands. Viewed across all plots and treatments, the relationship between the number of tree species and lichen diversity was strong for the hardwoods $(\mathrm{r}=0.862, P<$ $0.001)$ but not for pines $(\mathrm{r}=0.143, P=0.477)$. In contrast, no significant correlations were found when comparisons were restricted to plots within the burned and unburned treatments, although the relationship was marginal for the unburned hardwood category (Figure 2).

While fewer in total number, the lichen species found on the pines exhibited substantial overlap with those found on the hardwoods (Table 3). For example, three quarters $(75 \% \pm$ $10 \%$ mean and SD) of the lichen taxa growing on the pines were also found on the hardwoods in all but the twice-burned plots. The higher 
Table 2. List of tree species on which lichens were sampled, by species group (HW $=$ hardwood, PI $=$ pine) and treatment $(00=$ control; $10=$ thinned, not burned; $11=$ thinned, burned once; $12=$ thinned, burned twice). Values indicate tree frequency (the proportion of plots on which each tree species was present) by treatment and for the study. Taxa refers to the total number of lichen species found on each tree species.

\begin{tabular}{lccccccc}
\hline & & \multicolumn{9}{c}{ Treatment } & & \\
\cline { 3 - 5 } Tree species & Species group & $\mathbf{0 0}$ & $\mathbf{1 0}$ & $\mathbf{1 1}$ & $\mathbf{1 2}$ & Total & Taxa \\
\hline Pinus echinata & PI & 0.17 & 0.00 & 0.00 & 0.00 & 0.04 & 6 \\
Pinus serotina Michx. & PI & 0.33 & 0.00 & 0.17 & 0.00 & 0.11 & 10 \\
Pinus taeda & PI & 0.83 & 1.00 & 1.00 & 1.00 & 0.96 & 40 \\
Pinus virginiana & PI & 0.33 & 0.11 & 0.00 & 0.00 & 0.11 & 17 \\
Acer rubrum & HW & 1.00 & 0.89 & 0.00 & 0.00 & 0.52 & 56 \\
Carya pallida & HW & 0.33 & 0.00 & 0.00 & 0.00 & 0.07 & 29 \\
Cornus florida L. & HW & 0.33 & 0.00 & 0.00 & 0.00 & 0.07 & 21 \\
Diospyros virginiana L. & HW & 0.00 & 0.11 & 0.00 & 0.00 & 0.04 & 20 \\
Ilex opaca & HW & 0.83 & 0.89 & 0.00 & 0.00 & 0.48 & 27 \\
Liquidambar styraciflua & HW & 0.83 & 0.89 & 1.00 & 0.00 & 0.70 & 59 \\
Magnolia virginiana L. & HW & 0.17 & 0.00 & 0.00 & 0.00 & 0.04 & 9 \\
Nyssa sylvatica & HW & 0.50 & 0.22 & 0.17 & 0.00 & 0.22 & 36 \\
Quercus alba & HW & 0.33 & 0.11 & 0.00 & 0.00 & 0.11 & 28 \\
Quercus falcata & HW & 0.17 & 0.67 & 0.5 & 0.00 & 0.37 & 46 \\
Quercus nigra & HW & 0.67 & 0.22 & 0.00 & 0.00 & 0.22 & 35 \\
Quercus rubra L. & HW & 0.00 & 0.11 & 0.00 & 0.17 & 0.07 & 19 \\
Quercus stellata & HW & 0.17 & 0.11 & 0.00 & 0.00 & 0.07 & 29 \\
Sassafras albidum & HW & 0.50 & 0.89 & 0.17 & 0.17 & 0.48 & 45 \\
\hline
\end{tabular}

diversity of lichens found on the hardwood trees corresponded to more taxa in common among sampling heights than for the pines (Figure 3, top panels). Similarity values were comparable for the BAS and BOL interval of hardwoods $(0.51 \pm 0.01)$ and pines $(0.59 \pm$ 0.09) on the unburned plots, and appeared to remain stable for the hardwoods, yet declined for the pines on the burned plots, although reduced sample size due to missing values on the burned plots makes this comparison less clear cut (Figure 3, bottom panels). Similarity values for the BOL and CAN interval were generally lower than those determined for the more proximate BAS and BOL interval, and, when averaged across treatments, values for the hardwoods $(0.45 \pm 0.18)$ were more than double those for the pines $(0.18 \pm 0.01)$. The lowest similarity values were obtained for the most distant BAS and CAN interval.

The Anova model assessing overall lichen diversity suggested a highly significant treatment effect and, further, that the covariate representing the number of hardwood tree species was also important to consider (Figure 4, top panel). The subsequent contrasts revealed that burning substantially reduced the overall diversity of lichens in stands subject to one or two fires, where, on average, $36.0 \pm 5.2$ (least squares mean and SE) more taxa were represented in the unburned $(\mathrm{T}=00$ and $\mathrm{T}=10)$ than burned $(\mathrm{T}=11$ and $\mathrm{T}=12)$; no effect of 


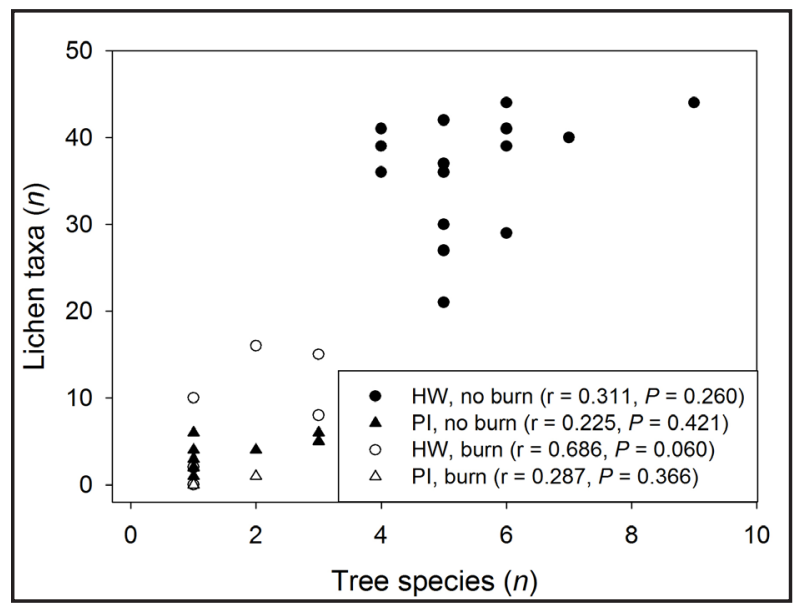

Figure 2. Relationship between the number of tree species and lichen species found growing on hardwood (HW) and pine (PI) tree species for burned and unburned plots. Pearson correlation coefficients and $P$-values.

thinning in the absence of burning was indicated (Figure 4). Models evaluating treatment effects on lichen diversity within the base and bole sampling heights yielded significant results, whereas no difference was apparent among samples taken from the canopy (Figure 5 , top panel). The number of lichen taxa found on the boles of trees in the unburned stands averaged $39.3 \pm 6.1$ more than in the burned stands.

In contrast to the findings for lichen diversity, analysis of overall cover did not yield a significant result, despite that the ratio of cover in the unburned to burned stands approaches 3:1 (Figure 4, bottom panel). Findings for the discrete base and bole sampling heights were more intuitive, in both cases suggesting that cover was substantially lower in the burned plots, by $0.28 \pm 0.08$ and $0.36 \pm 0.9$, respectively (Figure 5, bottom panel). Consistent with the findings from the sampling height analysis of the diversity variable, lichen cover within the canopy was apparently unaltered by burning or thinning.

We were unable to demonstrate differences in either the proportion of lichens exhibiting different growth forms (Figure 6, top panel) or reproductive modes (Figure 6, bottom panel) in response to the treatments. Lichens exhibiting a crustose growth form were most common across stands $0.72 \pm 0.14$ (mean and SD), and appeared to maintain a similar proportion of that total across treatments. While not supported by the results of any formal statistical tests, there did appear to be a tendency for the proportion of lichens with a foliose growth form to decline, and reciprocally for those with a fruticose growth form to increase, or more likely to simply persist within the burned stands (Figure 6, top panel). Similarly, while the statistics do not support any shift in the reproductive mode exhibited by the lichens persisting in treated stands, we did note an apparent downward trend in the occurrence of lichens exhibiting a sexual reproductive mode (Figure 6, bottom panel).

Assessment of the relationship between plot-level fire severity $\left(\mathrm{dNBR}_{\mathrm{MAX}}\right)$ and lichen variables was restricted to observations made

Table 3. The number of lichen species found within each sampling height and in total by species group $(\mathrm{HW}=$ hardwood, $\mathrm{PI}=$ pine $)$ and treatment $(00=$ control; $10=$ thinned, not burned; $11=$ thinned, burned once; 12 = thinned, burned twice). "Both" indicates the number of lichen taxa in common across the tree species groups, and na $=$ not applicable.

\begin{tabular}{|c|c|c|c|c|c|c|c|c|c|c|c|c|}
\hline \multirow[b]{2}{*}{ Treatment } & \multicolumn{3}{|c|}{ Base } & \multicolumn{3}{|c|}{ Bole } & \multicolumn{3}{|c|}{ Canopy } & \multicolumn{3}{|c|}{ Total } \\
\hline & HW & PI & Both & HW & PI & Both & HW & PI & Both & HW & PI & Both \\
\hline 00 & 34 & 7 & 7 & 57 & 16 & 10 & 42 & 17 & 14 & 71 & 27 & 21 \\
\hline 10 & 39 & 20 & 12 & 62 & 14 & 12 & 38 & 16 & 12 & 76 & 31 & 26 \\
\hline 11 & 8 & 3 & 2 & 2 & 16 & 4 & 1 & 58 & 4 & 3 & 0 & 49 \\
\hline 1 & 21 & 0 & $\mathrm{n}$ & a 4 & 0 & $\mathrm{n}$ & a 1 & 5 & 1 & 4 & 5 & 1 \\
\hline
\end{tabular}




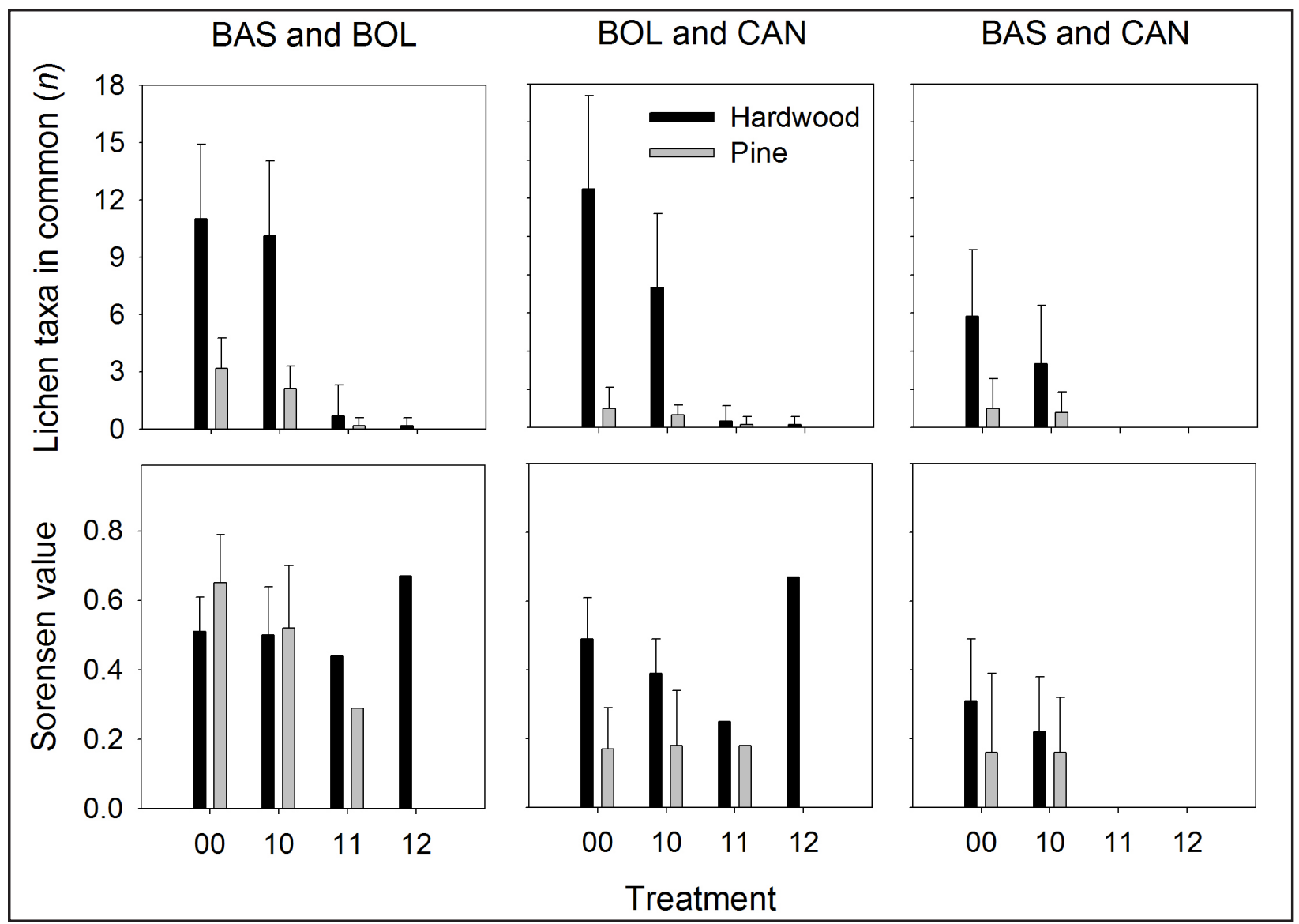

Figure 3. Similarity of lichen species found growing on hardwood and pine species at different sampling heights for the various treatments $(00=$ control; $10=$ thinned once, not burned; $11=$ thinned once, burned once; 12 = thinned once, burned twice). Means and standard deviations for the total number of species in common (top panels) and corresponding Sorensen similarity coefficient (bottom panels).

on pine trees because hardwoods were not well represented in the burned stands, particularly those that had been subjected to two fires. The range of dNBR values determined across the burn blocks (range $=-235$ to 621 ) was considerably wider than for $\mathrm{dNBR}_{\mathrm{MAX}}$ recorded on the study plots (range $=175$ to 466 ), and fell well within the range of possible values indicated for the methodology (approx. -600 to 1200). Similarly, the average dNBR values determined across all burn blocks $(168 \pm 140$, mean and SD) was both lower and more variable than the $\mathrm{dNBR}_{\mathrm{MAX}}$ values $(317 \pm 84)$ included in the analysis. Plots that were burned twice tended to have higher $\mathrm{dNBR}_{\mathrm{MAX}}$, values, but there was some overlap within the central part of the distribution (Figure 7). A signifi- cant negative correlation was observed between fire severity and the number of lichen taxa found on pine trees; however, no relationship was detected for lichen cover. One of the plots had a substantially higher average cover value than the others $\left(\mathrm{dNBR}_{\mathrm{MAX}}=367\right.$, cover $=$ $0.20)$, an observation that was attributable to high lichen cover within the crown (0.60), as opposed to the more exposed base or bole sections of the stem.

\section{DISCUSSION}

We acknowledge that findings from this research are tempered by the observational study design and that the variability in the timeframe over which the treatments were applied result- 


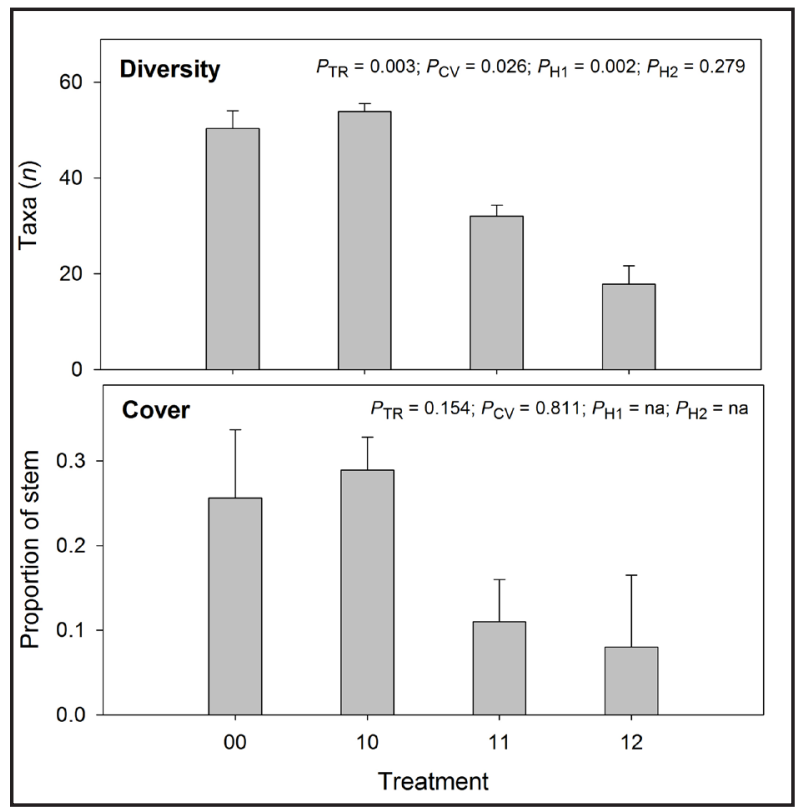

Figure 4. Overall trends in lichen diversity and cover for the different treatments $(00=$ control; 10 $=$ thinned once, not burned; $11=$ thinned once, burned once; 12 = thinned once, burned twice). Statistics from the GLM are presented, where $P_{\mathrm{TR}}$, $P_{\mathrm{CV}}, P_{\mathrm{H} 1}$, and $P_{\mathrm{H} 2}$ are $P$-values associated with tests for the effects of the treatment, covariate, and contrasts associated with burning $(00+10=11+12)$ and thinning $(00=10)$, respectively.

ed in different recovery periods when the lichen samples were collected. Also, hardwood trees in the treated stands tended to be younger and smaller than the pines, with correspondingly higher vulnerability to fire-induced mortality. However, available evidence suggests that the variable lag times between treatments and observations represented here are not likely to have been sufficient for lichen taxa to become reestablished or expand substantially following these types of disturbances (Jandt and Meyers 2000, Coxson and Marsh 2001).

The treatments documented in this study, prescribed burning and thinning, were undertaken to restore aspects of structure and composition that had been diminished through species conversion and long-term fire exclusion (Andreu et al. 2008, Nowacki and Abrams 2008, Ryan et al. 2013). Historic vegetation assemblages on these sites straddle the desig-

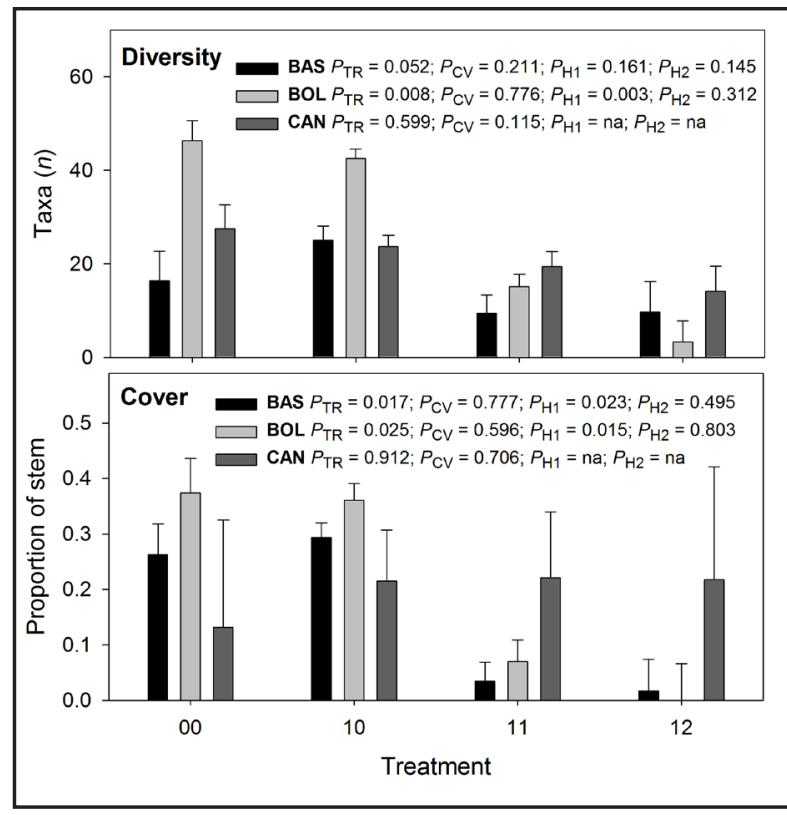

Figure 5. Trends in lichen diversity and cover by sampling height for the different treatments $(00=$ control; $10=$ thinned once, not burned; $11=$ thinned once, burned once; $12=$ thinned once, burned twice). Three discrete heights were analyzed: BAS, BOL, and CAN. Summary statistics from the GLM are presented, where $P_{\mathrm{TR}}, P_{\mathrm{CV}}, P_{\mathrm{H} 1}$, and $P_{\mathrm{H} 2}$ are $P$-values associated with tests for the effects of the treatment, covariate, and contrasts associated with burning $(00+10=11+12)$ and thinning $(00=10)$, respectively.

nations of Coastal Plain Oak-Loblolly Pine Forest and Inland Sand Dune and Ridge Woodland community types in Maryland (Harrison 2011), and these community types are known to harbor fire tolerant or pyrogenic vegetation supporting the use of prescribed burning as a management tool for restoration. Similarly, fire exclusion has led to tree densification with negative consequences for associated understory vegetation and wildlife (Taft 2009). We viewed the retention of off-site pines, noting that shortleaf pine would probably be more abundant than loblolly on the inland dune sites, as desirable, at least over the short term, because the highly flammable needle litter represents an important source of fuel that facilitates burning (sensu Kirkman et al. 2007). 


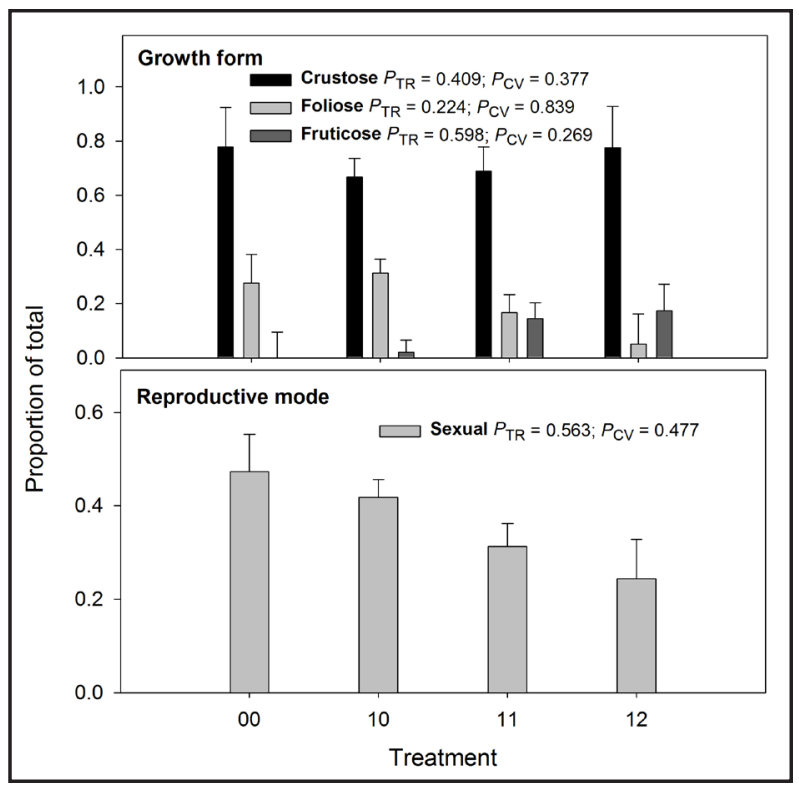

Figure 6. Trends in the proportion of lichen growth forms and reproductive modes determined across treatments $(00=$ control; $10=$ thinned once, not burned; 11 = thinned once, burned once; $12=$ thinned once, burned twice). Summary statistics from the GLM are presented, where $P_{\mathrm{TR}}, P_{\mathrm{CV}}, P_{\mathrm{H} 1}$, and $P_{\mathrm{H} 2}$ are $P$-values associated with tests for the effects of the treatment, covariate, and contrasts associated with burning $(00+10=11+12)$ and thinning $(00=10)$, respectively.

In combination, these practices have resulted in substantial increases in understory plant diversity and structural heterogeneity of the forest canopy (The Nature Conservancy's Nassawango Creek Preserve, Wicomico and Worcester counties, Maryland, USA, unpublished data), yet relatively little is known about associated impacts on understudied groups such as lichens (Lendemer and Allen 2014), which collectively comprise an overwhelming proportion of earth's biodiversity (Hawksworth 1991, Whitman et al. 1998, Mora et al. 2011). Lichens also often function as indicator and keystone organisms in many ecosystems, providing vital services for other members of the community (Brodo et al. 2001, Gianinazzi et al. 2010). Thus, the general lack of data documenting how management practices impact these groups represents a risk because

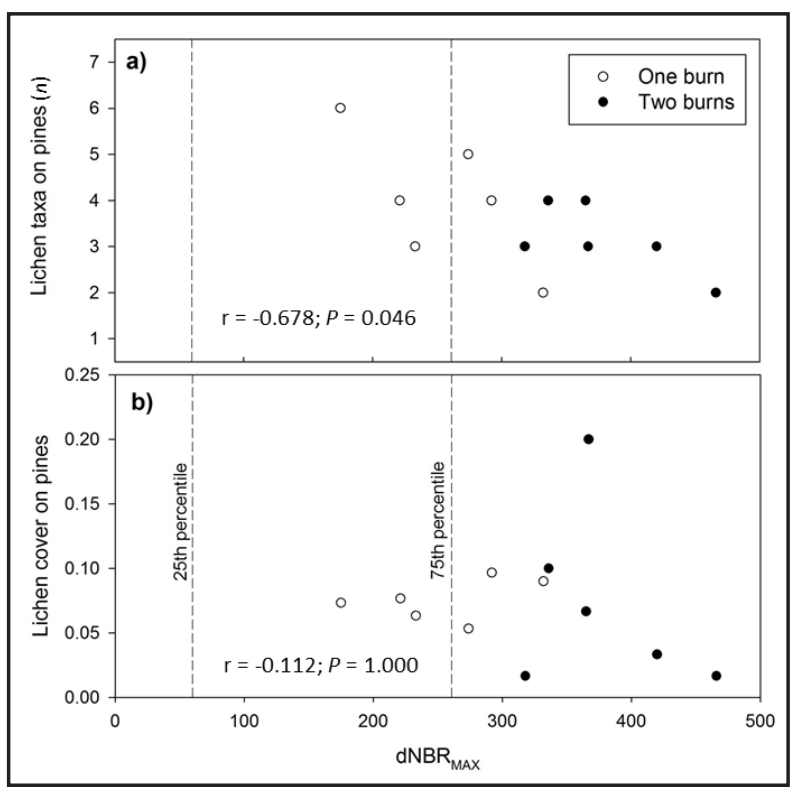

Figure 7. For pine trees only, the relationship between fire severity (dNBR) and a) the total number of lichen taxa, and b) lichen cover on plots subjected to one or two prescribed burns. Pearson correlation coefficient (r) and $P$-values. Dashed vertical lines represent the 25th and 75th percentiles of the dNBR values recorded across the burn blocks in 2009, 2011, and 2013 when prescribed burns were carried out.

they are being carried out and evaluated without considering one of the most diverse and important components of the ecosystem.

Our findings suggest that corticolous lichen communities similar to those present in the unburned stands reported on in this study have the potential to be substantially altered by the reintroduction of fire. Most notable was the apparent reduction in the diversity of lichen taxa found in burned stands (Figure 4, top panel). An explanation for this result may be traced, at least in part, to the reduced number and smaller stature of the otherwise generally higher lichen diversity supporting hardwood species present on the burned plots (Tables 1 and 2). Moreover, the canopy samples collected from the hardwoods on burned plots tended to be in closer proximity to the forest floor than for the larger pines, suggesting that exposure of canopy lichens to damage by the 
fires was also higher. We speculate that if more large, fire-tolerant hardwoods had been present in the burned stands, their canopies would have acted as more of a refugium for the lichen diversity, similar to that of pines. However, the extent to which the canopy layer represents a refugium from fire damage is tempered by the compositional dissimilarity among lichens encountered at the various sampling heights, with possible implications for post-fire colonization of the lower bole sections.

While the average number of lichen taxa found on pines was substantially lower than on the unburned hardwoods, those values remained fairly stable following the fires (Figure 2). Taken together, these findings support the idea that hardwoods harbor more diverse lichen communities than pines (Schmitt and Slack 1990), but this may be countered by a correspondingly higher vulnerability to damage by fire. A surprising result was that total lichen cover was not identified as significantly related to the treatments (Figure 4, bottom panel). We attribute this counterintuitive finding to two primary issues: first is the small sample size available for the Anova $(n=9$ stands) in conjunction with the relatively high variability in the cover variable among stands, and secondly that important differences were revealed for the base and bole sampling heights when they were analyzed independent of the null response of lichen cover in the canopy (Figure 5, bottom panel).

Thin-barked hardwoods are highly vulnerable to damage by fires independent of their size, a factor that has been used to infer the encroachment of fire-sensitive species across the landscape (e.g., Kirwan and Shugart 2000, Nowacki and Abrams 2008). Therefore, any lichen diversity associated with fire-susceptible hardwood species (e.g., red maple, American holly, American beech) should be assessed in the context of the broader restoration objectives for these natural areas by recognizing that mesophication of the tree community re- sulting from long-term fire exclusion may also have given rise to uncharacteristic lichen communities. Whether such reductions in lichen diversity will be offset by other species that become established on site-adapted hardwood trees is an open question requiring further study.

Abiotic factors such as humidity and solar insulation may represent stronger selective pressures on lichens than tree species, pushing lichen taxa to be more generalist in terms of their use of substrates (Gauslaa 2014). Some lichen species are known to depend on specific humidity levels for survival (Kantvilas and Minchin 1989), a condition that is altered by the removal of canopy trees as in a thinning. However, in this study, thinning in the absence of fire did not appear to result in meaningful changes in lichen diversity or cover. We speculate that this finding may be due to the relatively short and variable intervals following thinning (a period spanning over seven years between 2007 and 2013) when the samples were collected, in relation to rates of colonization by lichens. Alternatively, the lichen communities encountered in this study may be relatively insensitive to the magnitude of microclimatic changes brought about by the thinning treatments. Wind damage to pendulous lichens along the edges of harvest gaps was reported by Coxson and Stevenson (2005), but short-term impacts to lichens with other growth forms were somewhat ambiguous.

Previous research has documented differences in lichen communities based on the height gradient within trees, suggesting a level of discrimination among the base, bole, and canopy (Lesica et al. 1991, Peck and McCune 1997, Campbell and Coxson 2001, Cleavitt et al. 2009). While our findings generally support this observation, we also observed some notable similarities among the lichens on the bases and boles of hardwoods and pines, particularly on the unburned plots (Figure 3). Burning tended to eliminate lichens from the tree base, effectively disallowing the calcula- 
tion of similarity values for that sampling height in the burned plots, but values determined on the unburned plots were consistent with the hypothesis that lichen composition would become more different with increasing vertical separation in trees.

Evidence from other studies suggests that all lichen morphologies (i.e., crustose, foliose, fruticose) are highly vulnerable to fires (Romangni and Gries 1997, Wolseley and Aguirre-Hudson 1997, Johansson et al. 2012). While our findings do not provide any solid evidence contradicting this assertion, we did note an interesting trend in the data suggesting that lichens with a fruticose growth form may be better suited than foliose lichens to persist in fire adapted systems (Figure 6, top panel), but this contention will require further study. Crustose lichens were the dominant growth form in both the unburned and burned plots, where their relative abundance was unchanged. Lichens exhibiting the crustose growth form have relatively lower surface area exposed to fire compared to those with foliose and fruticose morphologies, providing a possible explanation for the neutral response of crustose lichens to fire observed here. In the case of fruticose lichens, we speculate they may have an advantage related to either the rapidity with which they can colonize new habitats, or to their ability to occupy microhabitats on the bark surface that are less exposed to fire.

Changes in the proportion of lichens with different reproductive modes following disturbance also has implications for colonization and persistence under a re-established burning regime. Previous research has indicated lichen soredia, which are small vegetative reproductive structures composed of fungal hyphae and algae (Brodo et al. 2001), are an effective dispersal mechanism for colonizing recently burned habitats (Eversman and Horton 2004). Over half of the lichens collected in this study primarily reproduce asexually through the dispersal of soredia or other specialized vegetative propagules. In contrast, the colonization of canopy branches by sexual species present in adjacent forest blocks might be expected considering the increased dispersal abilities of small fungal diaspores, such as ascospores, compared to relatively much larger asexual diaspores (Löbel et al. 2009, Wagner et al. 2006, Werth et al. 2006, Johansson et al. 2012, Lendemer et al. 2014). Our findings related to possible changes in the reproductive mode favored by lichens following thinning and burning were ambiguous (Figure 6, bottom panel), yet trended with the idea that a vegetative dispersal mechanism might dominate, at least over the short term.

It is reasonable to assert that the variability of fire effects on vegetation may not be adequately captured by a simple count of the number of times a stand has been burned. To address that possible limitation, the once- and twice-burned class variable used to represent the treatment in the Anova models was further explored using the dNBR approach to quantifying fire severity (http://www.mtbs.gov/index.html; e.g., Picotte and Robertson 2011) (Figure 7). While these results generally supported our use of the simpler class variable approach (i.e., lower values of dNBR were consistently associated with the once-burned plots and higher values with those that were burned twice), a considerable range of dNBR values was also represented within each burn treatment. The study plots were located at higher and drier than average landscape positions within the respective burn blocks, and were consistently associated with higher dNBR values. Anecdotal evidence suggests that the second fires in these areas burned hotter than the first as the result of abundant dead fuels generated by the initial burn, helping to explain why the burn count variable performed adequately in the context of this study. Findings for the pine trees based on this analysis are entirely consistent with the overall results presented in Figure 4, in which a stronger negative relationship is indicated for lichen diversity than for cover. 


\section{MANAGEMENT IMPLICATIONS}

While burning appears to have reduced the abundance and diversity of lichens previously found growing in the study area, we suggest that this outcome should be interpreted in light of restoration goals and in the context of an altered disturbance regime brought about by fire exclusion. From this perspective, it makes sense that the phenomenon of mesophication (Nowacki and Abrams 2008) would also extend to organisms for which component trees act as hosts. Available references suggest that a relatively frequent and low-intensity fire regime was characteristic of the coastal plain landscape where this study took place (Frost 1998, Guyette et al. 2012).

It is fairly well established that lichens are highly vulnerable to damage by fire, yet, through various avoidance and dispersal type mechanisms, they are still able to maintain a presence within fire-adapted systems (Longán et al. 1999, Eversman and Horton 2004, Johansson 2008). The initial fires in these areas burned under conditions that led to more intense fire behavior than desired over the long term (e.g., as a result of heavy fuel loads following thinning and timing in the early growing season), and may have led to greater impacts to the lichen communities. If so, these factors could be mitigated by initially reintroducing fires under conditions that would give rise to less active fire behavior while reducing fuel loads. Other studies have documented detrimental effects of forest densification on lichens, of the type that occurs in the absence of fires (Bond et al. 2005, Root et al. 2010), although this could conceivably be addressed through thinning.

Over time, repeated burning can be expected to act as a filter selecting for fire-tolerant tree species that will in turn provide stable substrates for similarly adapted lichens to col- onize (Bartos and Mueggler 1981, Espelta et al. 2003). The mature pine component of these stands is arguably already functioning in this way, whereas fire adapted hardwood species and associated lichen diversity still need to be recruited into these areas. For example, dry-site and fire-adapted oak species (e.g., post oak and black oak) are being sought as future overstory components in these areas, but recruitment in the context of a moderately frequent fire regime presents a challenge (see Arthur et al. 2012). Possible approaches to overcoming these limitations include: (1) waiting to re-introduce fire until repeated thinning of the pine canopy has released oaks already present in the understory or midstory and enabled them to grow to sizes (attain a bark thickness) that will be able to resist damage from subsequent understory fires, (2) using ignition techniques or other protection measures (e.g., raking; Williams et al. 2006) to guard selected areas and trees from fire damage within a burn block, and (3) periodically allowing for extended fire-free intervals so that new cohorts can attain sizes that will confer resistance to damage as in (1).

Recognizing and incorporating biodiversity concerns into forest and restoration management activities benefits from taking a multidisciplinary approach. This observational study of the impacts of thinning and fire on lichen communities within pine-dominated forests of the Mid-Atlantic Coastal Plain calls attention to a previously overlooked component of biodiversity — one that appears to be responsive to these types of treatments. Additional study will be required to determine whether a new equilibrium is established between the lichens and fire-adapted tree community on these sites where burning was reinstituted to benefit other more conspicuous aspects of biodiversity. 


\section{ACKNOWLEDGEMENTS}

The participation of J. Barton and J. Lendemer was supported by NSF DEB-1145511 (award to J. Lendemer and R. Harris). The authors thank B. McCune and R. McMullin for discussion of aspects of study design. J. Allen, N. Noell, G. Dettmann, and B. Palmer are thanked for their assistance with field sampling and laboratory study. A.M. Ruiz (also supported by NSF DEB1145511) aided significantly in the curation and digitization of voucher specimens generated by this study.

\section{LITERATURE CITED}

Agee J.K., and C.N. Skinner. 2005. Basic principles of forest fuel reduction treatments. Forest Ecology and Management 211: 83-96. doi: 10.1016/j.foreco.2005.01.034

Anderson, R.C. 1991. Presettlement forests of Illinois. Pages 9-19 in: G.V. Burger, J.E. Ebinger, and G.S. Wilhelm, editors. Proceedings of the oak woods management workshop. Eastern Illinois University, Charleston, South Carolina, USA.

Andreu, M., Z. Zobrist, and T. Hinckley. 2008. Management practices to support biodiversity in managed loblolly pine plantations. The School of Forest Resources, University of Florida, UF/IFAS Extension, Report FOR183, Gainesville, Florida, USA.

Antos, J.A., B. McCune, and C. Bara. 1983. The effect of fire on an ungrazed western Montana grassland. American Midland Naturalist 110: 354-364. doi: 10.2307/2425275

Arnold, A.E., J. Miadlikowska, K.L. Higgins, S.D. Sarvate, P. Gugger, A. Way, V. Hofstetter, F. Kauff, and F. Lutzoni. 2009. A phylogenetic estimation of trophic transition networks for ascomycetous fungi: are lichens cradles of symbiotrophic fungal diversification? Systematic Biology 58: 283-297. doi: 10.1093/sysbio/syp001

Arthur, M.A., H.D. Alexander, D.C. Dey, C.J. Schweitzer, and D.L. Loftis. 2012. Refining the oak-fire hypothesis for management of oak-dominated forests of the eastern United States. Journal of Forestry 110: 257-266. doi: 10.5849/jof.11-080

Auch, R.F. 2000. Mid-Atlantic Coastal Plain. US Geological Survey, Land Cover Trends Project, Reston, Virginia, USA.

Bartos, D.L., and W.F. Mueggler. 1981. Early succession in aspen communities following fire in western Wyoming. Journal of Range Management Archives 34: 315-318. doi: $10.2307 / 3897859$

Bond W.J., F.I. Woodward, and G.F. Midgley. 2005. The global distribution of ecosystems in a world without fire. New Phytologist 165: 525-538. doi: 10.1111/j.1469-8137.2004.01252.x

Bowker, M.A., J. Belnap, R. Rosentreter, and B. Graham. 2004. Wildfire-resistant biological crusts and fire-induced loss of soil stability in Palouse prairies, USA. Applied Soil Ecology 26: 41-51. doi: 10.1016/j.apsoil.2003.10.005

Brodo, I.M., S.D. Sharnoff, and S. Sharnoff. 2001. Lichens of North America. Yale University Press, New Haven, Connecticut, USA, and London, England, United Kingdom.

Brooks, M.L., C.M. D’Antonio, D.M. Richardson, J.B. Grace, J.E. Keeley, J.M. DiTomaso, R.J. Hobbs, M. Pellant, and D. Pyke. 2004. Effects of invasive alien plants on fire regimes. BioScience 54: 677-688. doi: 10.1641/0006-3568(2004)054[0677:EOIAPO]2.0.CO;2

Campbell, J., and D.S. Coxson. 2001. Canopy microclimate and arboreal lichen loading in subalpine spruce-fir forest. Canadian Journal of Botany 79: 537-555. doi: 10.1139/b01-025

Cleavitt, N.L., A.C. Dibble, and D.A. Werier. 2009. Influence of tree composition upon epiphytic macrolichens and bryophytes in old forests of Acadia National Park, Maine. The Bryologist 112: 467-487. doi: 10.1639/0007-2745-112.3.467 
Colwell, R.K. 2013. EstimateS: statistical estimation of species richness and shared species from samples. Version 9 and earlier, user's guide and application. University of Connecticut, Storrs, USA.

Coxson, D.S., and J. Marsh. 2001. Lichen chronosequences (post-fire and post-harvest) in lodgepole pine (Pinus contorta) forests of northern-interior British Columbia. Canadian Journal of Botany 79: 1449-1464. doi: 10.1139/b01-127

Coxson, D.S., and S.K. Stevenson. 2005. Retention of canopy lichens after partial-cut harvesting in wet-belt interior cedar-hemlock forests, British Columbia, Canada. Forest Ecology and Management 204: 97-112. doi: 10.1016/j.foreco.2004.09.002

Culberson, W.L. 1955. The corticolous communities of lichens and bryophytes in the upland forests of northern Wisconsin. Ecological Monographs 25: 215-231. doi: 10.2307/1943551

Delcourt, H.R., and P.A. Delcourt. 1997. Pre-Columbian Native American use of fire on southern Appalachian landscapes. Conservation Biology 11: 1010-1014. doi: 10.1046/j.1523-1739.1997.96338.x

Denny, C.S., and P.J. Owens. 1979. Sand dunes on the Central Delmarva Peninsula, Maryland and Delaware. US Geological Survey Professional Paper 1067-C, Washington, D.C., USA.

Egan, D. 2005. The historical ecology handbook: a restorationist's guide to reference ecosystems. Island Press, Washington, D.C., USA.

Espelta, J.M., J. Retana, and A. Habrouk. 2003. Resprouting patterns after fire and response to stool cleaning of two coexisting Mediterranean oaks with contrasting leaf habits on two different sites. Forest Ecology and Management 179: 401-414. doi: 10.1016/S0378-1127 (02)00541-8

Eversman, S., and D. Horton. 2004. Recolonization of burned substrates by lichens and mosses in Yellowstone National Park. Northwest Science 78: 85-92.

FEIS [Fire Effects Information System]. 2015. FEIS home page. <http://www.feis-crs.org/ beta/>. Accessed 28 February 2015.

Frost, C.C. 1998. Presettlement fire frequency regimes of the United States: a first approximation. Pages 70-81 in: T.L. Pruden and L.A. Brennan, editors. Proceedings of the 20th Tall Timbers Fire Ecology Conference: fire in ecosystem management: shifting the paradigm from suppression to prescription. Tall Timbers Research Inc., Tallahassee, Florida, USA.

Gauslaa, Y. 2014. Rain, dew and humid air as drivers of morphology, function and spatial distribution in epiphytic lichens. The Lichenologist 46: 1-16. doi: 10.1017/S0024282913000753

Gianinazzi, S., A. Gollotte, M.N. Binet, D. van Tuinen, D. Redecker, and D. Wipf. 2010. Agroecology: the key role of arbuscular mycorrhizas in ecosystem services. Mycorrhiza 20: 519530. doi: 10.1007/s00572-010-0333-3

Guyette, R.P., M.C. Stambaugh, D.C. Dey, and R.M. Muzika. 2012. Predicting fire frequency with chemistry and climate. Ecosystems 15: 322-335. doi: 10.1007/s10021-011-9512-0

Harrison, J.W. 2011. The natural communities of Maryland: 2011 working list of ecological community groups and community types. Maryland Department of Natural Resources, Wildlife and Heritage Service, Natural Heritage Program, Annapolis, Maryland, USA.

Hartmann, H., G. Daoust, B. Bigué, and C. Messier. 2010. Negative or positive effects of plantation and intensive forestry on biodiversity: a matter of scale and perspective. The Forestry Chronicle 86: 354-364. doi: 10.5558/tfc86354-3

Hawksworth, D.L. 1991. The fungal dimension of biodiversity: magnitude, significance and conservation. Mycological Research 95: 641-655. doi: 10.1016/S0953-7562(09)80810-1 
Hodkinson, B.P., and F. Lutzoni. 2009. A microbiotic survey of lichen-associated bacteria reveals a new lineage from the Rhizobiales. Symbiosis 49: 163-180. doi: 10.1007/s13199-009-0049-3

Holt, E.A., and P.M. Severns. 2005. The effects of prescribed burning on wet prairie lichen communities. Natural Areas Journal 25: 130-136.

IPCC [Intergovernmental Panel on Climate Change]. 2013. Climate change 2013: the physical science basis. Contribution of Working Group 1 to the fifth assessment report of the Intergovernmental Panel on Climate Change. Cambridge University Press, Cambridge, England, United Kingdom.

Jandt, R.R., and C.R. Meyers. 2000. Recovery of lichen in tussock tundra following fire in northwestern Alaska. BLM-Alaska Open File Report 82, Anchorage, Alaska, USA. doi: 10.5962/bhl.title.61209

Johansson, P. 2008. Consequences of disturbance on epiphytic lichens in boreal and near boreal forests. Biological Conservation 141: 1933-1944. doi: 10.1016/j.biocon.2008.05.013

Johansson, V., T. Ranius, and T. Snäll. 2012. Epiphyte metapopulation dynamics are explained by species traits, connectivity, and patch dynamics. Ecology 93: 235-241. doi: 10.1890/11-0760.1

Johansson, P., and P.B. Reich. 2005. Population size and fire intensity determine post-fire abundance in grassland lichens. Applied Vegetation Science 8: 193-198. doi: 10.1111/j.1654-109X.2005.tb00645.x

Kantvilas, G., and P.R. Minchin. 1989. An analysis of epiphytic lichen communities in Tasmanian cool temperate rainforest. Vegetatio 84: 99-112. doi: 10.1007/BF00036510

Kirkman, K.L, R.J. Mitchell, M.J. Kaeser, S.D. Pecot, and K.L. Coffey. 2007. The perpetual forest: using undesirable species to bridge restoration. Journal of Applied Ecology 44: 604-614. doi: $10.1111 / \mathrm{j} .1365-2664.2007 .01310 . x$

Kirwan, J.L., and H.H. Shugart. 2000. Vegetation and two indices of fire on the Delmarva Peninsula. Journal of the Torrey Botanical Society 127: 44-50. doi: 10.2307/3088746

Klein, D.R. 1982. Fire, lichens, and caribou. Journal of Range Management 35: 390-395. doi: $10.2307 / 3898326$

Kohm, K.A., and J.F. Franklin. 1997. Creating a forestry for the 21 st century: the science of ecosystem management. Island Press, Washington, D.C., USA.

Lendemer, J.C., and J. Allen. 2014. Lichen biodiversity under threat from sea-level rise in the Atlantic Coastal Plain. BioScience 64: 923-931. doi: 10.1093/biosci/biu136

Lendemer, J.C., E. Tripp, and J.W. Sheard. 2014. A review of Rinodina (Physciaceae) in Great Smoky Mountains National Park highlights the growing significance of this "island of biodiversity" in eastern North America. The Bryologist 117: 259-281. doi: 10.1639/0007-2745-117.3.259

Lesica, P., B. McCune, S.V. Cooper, and W.S. Hong. 1991. Differences in lichen and bryophyte communities between old-growth and managed second-growth forests in the Swan Valley, Montana. Canadian Journal of Botany 69: 1745-1755. doi: 10.1139/b91-222

Löbel, S., T. Snäll, and H. Rydin. 2009. Mating system, reproduction mode and diaspore affect metacommunity diversity. Journal of Ecology 97: 176-185. doi: 10.1111/j.1365-2745.2008.01459.x

Longán, A., E. Gaya, and A. Gómez-Bolea. 1999. Post-fire colonization of a Mediterranean forest stand by epiphytic lichens. The Lichenologist 31: 389-395. doi: 10.1017/ S0024282999000493 
McCune, B., J. Dey, J. Peck, K. Heiman, and S. Will-Wolf. 1997. Regional gradients in lichen communities of the southeast United States. The Bryologist 100: 145-158. doi: 10.1639/0007-2745(1997)100[145:RGILCO]2.0.CO;2

Mistry, J. 1998. Corticolous lichens as potential bioindicators of fire history: a study in the cerrado of the Distrito Federal, central Brazil. Journal of Biogeography 25: 409-441. doi: 10.1046/j.1365-2699.1998.2530409.x

Mitchell, R.J., J.K. Hiers, J.J. O’Brien, S.B. Jack, and R.T. Engstrom. 2006. Silviculture that sustains: the nexus between silviculture, frequent prescribed fire, and conservation of biodiversity in longleaf pine forests of the southeastern United States. Canadian Journal of Forest Research 36: 2724-2736. doi: 10.1139/x06-100

Mora, C., D.P. Tittensor, S. Adl, A.G.B. Simpson, and B. Worm. 2011. How many species are there on Earth and in the ocean. PLoS Biology 9(8): e1001127. doi: 10.1371/journal. pbio. 1001127

Muir, P.S., and B. McCune. 1988. Lichens, tree growth, and foliar symptoms of air pollution: are the stories consistent? Journal of Environmental Quality 17: 361-370. doi: 10.2134/ jeq1988.00472425001700030004x

Nash III, T.H. 1975. Influence of effluents from a zinc factory on lichens. Ecological Monographs 45: 183-198. doi: 10.2307/1942406

NatureServe. 2011. National Vegetation Classification. <http://usnvc.org/data-standard/natural-vegetation-classification/>. Accessed 8 February 2011.

Nowacki, G.J., and M.D. Abrams. 2008. The demise of fire and "mesophication" of forests in the eastern United States. BioScience 58: 123-138. doi: 10.1641/B580207

Peck, J.E., and B. McCune. 1997. Remnant trees and canopy lichen communities in western Oregon: a retrospective approach. Ecological Applications 7: 1181-1187. doi: 10.1890/1051-0761(1997)007[1181:RTACLC]2.0.CO;2

Picotte, J.J., and K.M. Robertson. 2011. Validation of remote sensing of burn severity in southeastern US ecosystems. International Journal of Wildland Fire 20: 453-464. doi: 10.1071/ WF10013

Platt, W.J. 1999. Southeastern pine savannas. Pages 23-51 in: R.C. Anderson, J.S. Fralish, and J. Baskin, editors. The savanna, barren, and rock outcrop communities of North America. Cambridge University Press, Cambridge, England, United Kingdom.

Pyne, S.J. 1982. Fire in America: a cultural history of wildland and rural fire. Princeton University Press, Princeton, New Jersey, USA.

Pyne, S.J. 2010. America's fires. A historical context for policy and practice. Forest History Society, Durham, North Carolina, USA.

Reinhart, K.O., and E.S. Menges. 2004. Effects of re-introducing fire to a central Florida sandhill community. Applied Vegetation Science 7: 141-150. doi: 10.1111/j.1654-109X.2004. tb00604.x

Romagni, J., and C. Gries. 1997. Assessment of fire damage to epiphytic lichens in southeastern Arizona. The Bryologist 100: 102-108. doi: 10.1639/0007-2745(1997)100[102:AOFDTE] 2.0.CO;2

Root, H.T., B. McCune, and P. Neitlich. 2010. Lichen habitat may be enhanced by thinning treatments in young Tsuga heterophylla-Pseudotsuga menziesii forests. The Bryologist 113: 292-307. doi: 10.1639/0007-2745-113.2.292

Ryan, K.C., E.E. Knapp, and J.M. Varner. 2013. Prescribed fire in North American forests and woodlands: history, current practice, and challenges. Frontiers in Ecology and the Environment 11(s1): e15-e24. doi: 10.1890/120329 
Schmitt, C.K., and N.G. Slack. 1990. Host specificity of epiphytic lichens and bryophytes: a comparison of the Adirondack Mountains (New York) and the southern Blue Ridge Mountains (North Carolina). The Bryologist 93: 257-274. doi: 10.2307/3243509

Seymour, R.S., A.S. White, and P.G. deMaynadier. 2002. Natural disturbance regimes in northeastern North America — evaluating silvicultural systems using natural scales and frequencies. Forest Ecology and Management 155: 357-367. doi: 10.1016/S0378-1127(01)00572-2

Showman, R.E. 1981. Lichen recolonization following air quality improvement. The Bryologist 84: 492-497. doi: 10.2307/3242556

Sørensen, T. 1948. A method of establishing groups of equal amplitude in plant sociology based on similarity of species and its application to analyses of the vegetation on Danish commons. Biologiske Skrifter 5: 1-34.

Taft, J.B. 2009. Effects of overstory stand density and fire on ground layer vegetation in oak woodland and savanna habitats. Pages 21-39 in: T.F. Hutchinson, editor. Proceedings of the third conference: fire in Eastern oak forests. USDA Forest Service General Technical Report NRS-P-46, Northern Research Station, Newtown Square, Pennsylvania, USA.

Wagner, H.H., S. Werth, J.M. Kalwij, J.C. Bolli, and C. Scheidegger. 2006. Modeling forest colonization by an epiphytic lichen using a landscape genetic approach. Landscape Ecology 21: 849-865. doi: 10.1007/s 10980-005-5567-7

Werth, S., H.H. Wagner, R. Holderegger, J.M. Kalwij, and C. Scheidegger. 2006. Effect of disturbances on the genetic diversity of an old-growth forest associated lichen. Molecular Ecology 15: 911-921. doi: 10.1111/j.1365-294X.2006.02838.x

Whitman, W.B., D.C. Coleman, and W.J. Wiebe. 1998. Prokaryotes: the unseen majority. Proceedings of the National Academy of Sciences USA 95: 6578-6583. doi: 10.1073/ pnas.95.12.6578

Whitney, G.G. 1994. From coastal wilderness to fruited plain: a history of environmental change in temperate North America from 1500 to the present. Cambridge University Press, Cambridge, England, United Kingdom.

Wiens, J.A., G.D. Hayward, H.D. Safford, and C. Giffen. 2012. Historical environmental variation in conservation and natural resource management. John Wiley \& Sons, Oxford, England, United Kingdom. doi: 10.1002/9781118329726

Williams, B.W., E.B. Moser, J.K. Hiers, K. Gault, and D.K. Thurber. 2006. Protecting red-cockaded woodpecker cavity trees predisposed to fire-induced mortality. Journal of Wildlife Management 70: 702-707. doi: 10.2193/0022-541X(2006)70[702:PRWCTP]2.0.CO;2

Wolf, J. 2004. A 200-year fire history in a remnant oak savanna in southeastern Wisconsin. American Midland Naturalist 152: 201-202. doi: 10.1674/0003-0031(2004)152[0201: AYFHIA]2.0.CO;2

Wolseley, P.A. 1995. A global perspective on the status of lichens and their conservation. Pages 11-27 in: C. Scheidegger, P.A. Wolseley, and G. Thor, editors. Conservation biology of lichenised fungi. Mitteilungen der Eidgenössischen Forschungsanstalt für Wald, Schnee und Landschaft, Birmensdorf, Switzerland.

Wolseley, P.A., and B. Aguirre-Hudson. 1997. Fire in tropical dry forests: corticolous lichens as indicators of recent ecological changes in Thailand. Journal of Biogeography 24: 345-362. doi: 10.1046/j.1365-2699.1997.00125.x 